\title{
STRATEGI PENGELOLAAN PARIWISATA BERKELANJUTAN DI KAWASAN WISATA ALAM SUMBER MARON, KABUPATEN MALANG
}

\section{STRATEGY OF SUSTAINABLE TOURISM MANAGEMENT IN WISATA ALAM SUMBER MARON, MALANG REGENCY}

\author{
Agnes Caesarika GP, Muhamad Muhamad*, Chafid Fandeli \\ Tourism Study Program, Postgraduate School UGM
}

Submitted:27-08-2020; Revised:21-09-2021; Accepted: 24-09-2021

\begin{abstract}
Wisata Alam Sumber Maron is a tourist destination in Malang Regency which is currently experiencing a surge in tourists. In addition, there are problems with the conversion of land from plantations to developed land. Both of these problems have an impact on the quality of the environment in Wisata Alam Sumber Maron, causing the tourist destination area to be unsustainable. The purpose of this research is to analyze the management strategies that can be applied in Wisata Alam Sumber Maron. The data analysis used is an analysis of the carrying capacity of the environment to determine its physical factors, stakeholder analysis to determine social factors and analysis of travel costs to determine economic factors. Based on the method used, the final result is ha the effective carrying capacity at the Wisata Alam Sumber Maron is 179 people/day. This figure is then used as a guideline for strategy formulation. The management strategy is formulated using the 4 pillars of tourism method as stated in the Undang-Undang Number 10 of 2009 about Kepariwisataan, namely the tourism industry, destinations, marketing, and tourism institutions.
\end{abstract}

Keywords: Management Strategy; Sustainable Touris; Nature Tourism.

\section{ABSTRAK}

Wisata Alam Sumber Maron merupakan destinasi wisata yang berada di Kabupaten Malang dimana saat ini tengah mengalami kelonjakan wisatawan. Selain itu, terdapat permasalahan alih fungsi lahan dari perkebunan menjadi lahan terbangun. Kedua permasalahan tersebut berdampak terhadap kualitas lingkungan di Wisata Alam Sumber Maron sehingga menyebabkan kawasan destinasi wisata tersebut tidak berkelanjutan. Tujuan penelitian ini untuk menganalisis strategi pengelolaan yang dapat diterapkan di Wisata Alam Sumber Maron. Analisis data yang digunakan adalah analisis daya dukung lingkungan untuk mengetahui faktor fisiknya, analisis pemangku kepentingan untuk mengetahui faktor sosial dan analisis biaya perjalanan untuk mengetahui faktor ekonominya. Berdasarkan metode digunakan didapatkan hasil akhir yaitu daya dukung efektif pada lokasi Wisata Alam Sumber Maron adalah 179 orang/hari. Angka tersebut kemudian dijadikan pedoman untuk penyusunan strategi. Strategi pengelolaan disusun menggunakan metode 4 pilar kepariwisataan yang tercantum dalam Undang-Undang Nomor 10 Tahun 2009 tentang Kepariwisataan yaitu industri pariwisata, destinasi, pemasaran, dan kelembagaan pariwisata

Kata kunci : Strategi Pengelolaan; Pariwisata Berkelanjutan; Wisata Alam.

* Corresponding author: drmuhammad@ugm.ac.id

Copyright @2021 THE AUTHOR(S). This article is distributed under a Creative Commons Attribution-Share Alike 4.0 International license. Jurnal Teknosains is published by the Graduate School of Universitas Gadjah Mada 


\section{PENDAHULUAN}

Pariwisata berkelanjutan merupakan pariwisata yang mampu memaksimalkan dampak positif dan meminimalkan dampak negatif dengan lingkungan sekitar. Pembangunan pariwisata harus didasarkan pada kriteria keberlanjutan yang artinya bahwa pembangunan dapat didukung secara ekologis dalam jangka panjang, sekaligus layak secara ekonomi, adil secara etika dan sosial terhadap masyarakat (Piagam Pariwisata Berkelanjutan, 1995). Pariwisata alam telah menjadi salah satu pilihan wisata yang menyajikan keindahan alam dan lingkungan sebagai daya tarik utama. Namun untuk menjaga keberlangsungannya, perlu ditetapkan daya dukung lingkungan untuk mengetahui kemampuan lingkungan menetralisir parameter pencemar dalam rangka pemulihan kondisi lingkungan seperti semula. Daya dukung lingkungan merupakan sebuah alat untuk memberikan batasan atas pertumbuhan suatu populasi, dimana jumlah populasi tersebut tidak dapat lagi didukung oleh sarana sumber daya dan lingkungan yang ada. Atau secara lebih singkat dapat dijelaskan sebagai batas aktivitas manusia yang berperan dalam perubahan lingkungan (Arida, 2015).

Wisata Alam Sumber Maron merupakan salah satu objek wisata alam yang berada di Dusun Adiluwih, Desa Karangsuko, Kecamatan Pagelaran, Kabupaten Malang. Saat ini tengah beredar berita atau isu di masyarakat bahwa Wisata Alam Sumber Maron kini menjadi salah satu wisata alam yang mengalami lonjakan wisatawan. Wisata Alam Sumber Maron mampu mendatangkan 400 wisatawan di hari kerja, sedangkan untuk akhir pekan atau weekend, wisatawan mampu mencapai minimal 5.000 pengunjung dalam satu hari. Berikut adalah data jumlah wisatawan Wisata Alam Sumber Maron sejak Bulan Januari hingga September 2019 yang dapat dilihat pada Tabel 1.

Tabel 1.

Jumlah Kunjungan Wisatawan di Wisata Alam

Sumber Maron Bulan Januari - September 2019

\begin{tabular}{|c|c|c|c|c|}
\hline \multirow{2}{*}{ No } & \multirow{2}{*}{ Bulan } & \multicolumn{2}{|c|}{ Kunjungan } & \multirow{2}{*}{ Tota } \\
\hline & & Domestik & \begin{tabular}{|l|} 
Mancanegara \\
\end{tabular} & \\
\hline 1 & Januari & 26.980 & 20 & 27.000 \\
\hline 2 & Februari & 11.620 & 15 & 11.635 \\
\hline 3 & Maret & 41.025 & 25 & 41.055 \\
\hline 4 & April & 48.611 & 35 & 48.646 \\
\hline 5 & Mei & 12.670 & 12 & 12.682 \\
\hline 6 & Juni & 87.243 & 15 & 87.258 \\
\hline 7 & Juli & 75.772 & 25 & 75.797 \\
\hline 8 & Agustus & 34.504 & 17 & 34.487 \\
\hline 9 & September & 50.350 & 31 & 50.381 \\
\hline
\end{tabular}

Sumber: Data Pengelola Wisata Alam Sumber Maron, 2019.

Kini Wisata Alam Sumber Maron sudah tidak dapat disebut sebagai wisata berbasis alam melainkan wisata massal (mass tourism). Pengelola dari Wisata Alam Sumber Maron masih mengabaikan kapasitas penerimaan wisatawan dan berorientasi pada kuantitas wisatawan yang berkunjung. Pariwisata berbasis massal seperti ini memiliki peluang menimbulkan degradasi bahkan destruksi atas lingkungan, baik lingkungan alam maupun budaya dan sosial (Mutaqin, 2017).
Makin meningkatnya jumlah wisatawan yang berkunjung membuat lingkungan di Wisata Alam Sumber Maron menjadi tidak seimbang. Fenomena yang sangat mencolok ialah banyaknya area persawahan, perkebunan dan area resapan air yang mengalami alih fungsi lahan menjadi tempat makan (warung). Aspek yang erat kaitannya dengan kasus alih fungsi lahan di Wisata Alam Sumber Maron adalah alih fungsi lahan yang demikian dapat bersifat 
permanen (Utomo, 1992). Tanah tersebut milik masyarakat (individual) sehingga pengelola masih belum merasa berhak untuk melarang masyarakat. Pihak pengelola juga belum resmi menarik pajak dari hasil penjualan tempat makan tersebut menjadikan masyarakat tetap memikirkan peluang perekonomian tanpa memedulikan dampak atau efek ke depannya. Efek dari pertumbuhan tempat makan yang melesat tersebut nyatanya juga berdampak pada kualitas air sungai yang berada di Wisata Alam Sumber Maron. Hal tersebut dikarenakan pemilik warung tidak memperhatikan saluran pembuangan dari limbah tempat makan mereka. Hal itu membuat wisatawan kerap mencium bau busuk di titik-titik tertentu.

Selain berdampak terhadap lingkungan dari Wisata Alam Sumber Maron, nyatanya terdapat peraturan pemerintah yaitu UndangUndang Republik Indonesia Nomor 26 Tahun 2007 Tentang Penataan Ruang yang menjelaskan bahwa lahan yang harus terbebas dari bangunan paling sedikit adalah 30\%. Sementara ini di Wisata Alam Sumber Maron memiliki luas area untuk wisata sebesar 13.000 $\mathrm{m}^{2}$ dan luas lahan terbangun sebesar $6.038 \mathrm{~m}^{2}$. Artinya bahwa lahan terbangun di kawasan ini sebesar $46 \%$ dan lahan tidak terbangun (ruang terbuka hijau) sebesar 54\%. Dari persentase tersebut apabila tidak ada penanganan atau pembatasan maka akan melebihi batas ketentuan dari ruang terbuka hijau yang telah tertulis dalam peraturan pemerintah.

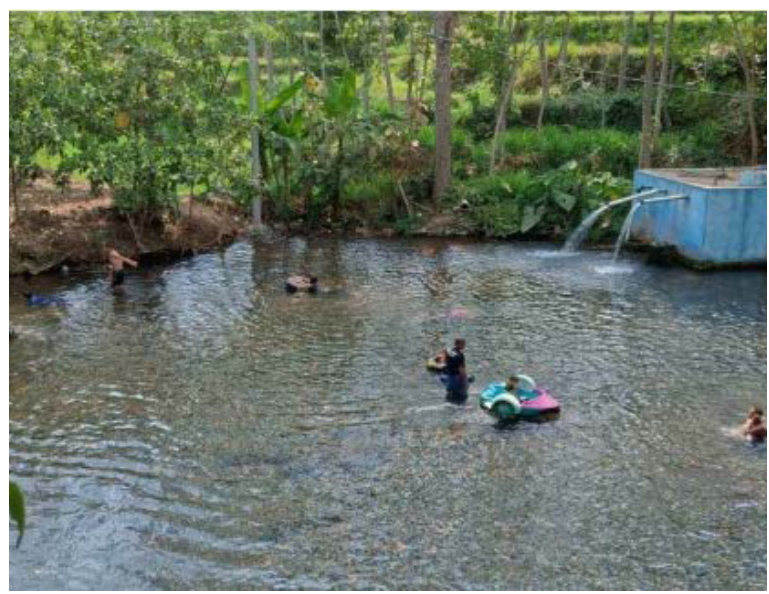

Gambar 1.

Zona A Wisata Alam Sumber Maron

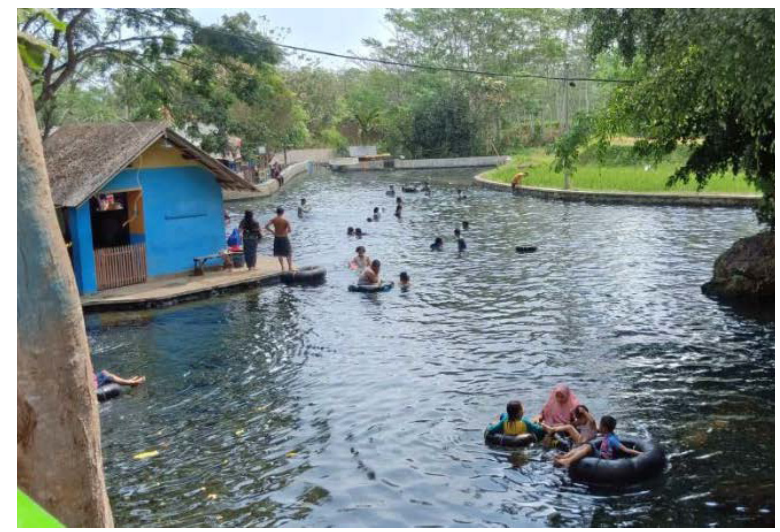

Gambar 2

Zona B Wisata Alam Sumber Maron

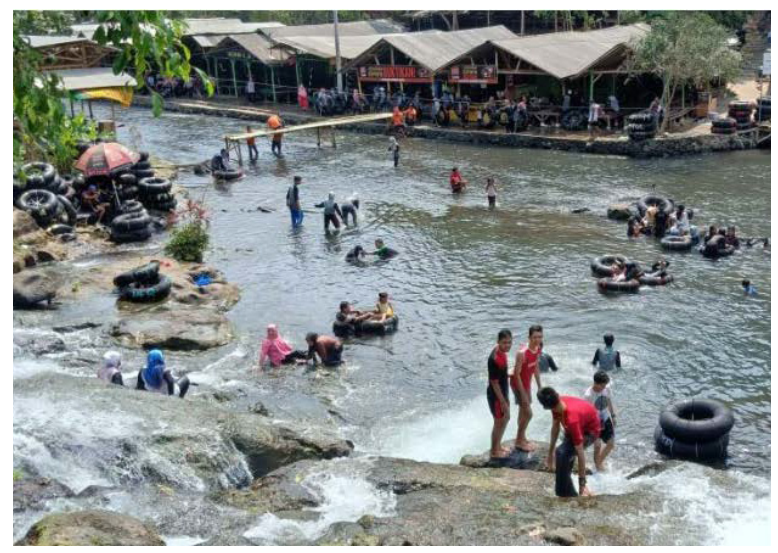

Gambar 3.

Zona $\mathrm{C}$ yang menyerupai air terjun dan sungai. (Sumber: Dokumen Penulis,2020)

Menurut Damanik dan Weber (2006), pembangunan sumber daya pariwisata yang berkelanjutan mampu memberikan keuntungan yang optimal bagi pemangku kepentingan dan nilai kepuasan optimal bagi wisatawan dalam jangka panjang. Untuk itu perlu dilakukannya sebuah penelitian dan kajian dengan tema "Strategi Pengelolaan Pariwisata Berkelanjutan di Kawasan Wisata Alam Sumber Maron Kecamatan Pagelaran, Kabupaten Malang, Jawa Timur". Kajian daya dukung lingkungan bisa menjadi alat yang paling utama untuk dilakukan guna mengevaluasi pengelolaan dan mengoptimalkan kegiatan wisata dari segi lingkungannya. Analisis stakeholder yang memperhatikan keoptimalan bagi pemangku kepentingan yang mengelola wisata tersebut dan Analisis Travel Cost Methods yang 
memperhatikan nilai perekonomian serta kepuasan optimal dari wisatawan.

Hasil dari kajian ini nantinya akan digunakan sebagai pedoman untuk mengembangkan atau menyusun strategi tata kelola perencanaan objek daya tarik dari Wisata Alam Sumber Maron dengan berlandaskan pada empat pilar pariwisata agar menjadi destinasi pariwisata yang eksklusif dan berkelanjutan. Penelitian ini bertujuan untuk mengetahui jumlah wisatawan di Wisata Alam Sumber Maron Kabupaten Malang, untuk mengetahui aktivitas pariwisata yang disajikan, untuk mengetahui daya dukung efektif di Kawasan Wisata Alam Sumber Maron dan untuk mengembangkan strategi tata kelola dari Wisata Alam Sumber Maron sehingga menjadikan sebagai destinasi pariwisata yang berkelanjutan.

Penelitian ini merupakan penelitian survey dengan pendekatan kuantitatif. Penelitian ini menggunakan data primer dan sekunder. Data primer pada penelitian ini berupa variabelvariabel yang digunakan untuk perhitungan daya dukung lingkungan, analisis stakeholder dan metode travel cost (biaya perjalanan). Data sekunder meliputi informasi tambahan yang bersumber dari buku, jurnal, laporan tahunan, literatur dan dokumen pemerintah lainnya yang relevan dengan penelitian ini.

Lokasi penelitian berada di Wisata Alam Sumber Maron. Secara administrasi wisata ini terletak di Dusun Adiluwih, Desa Karangsuko, Kecamatan Pagelaran, Kabupaten Malang. Wisata Alam Sumber Maron memiliki luas area sebesar $29.610 \mathrm{~m}^{2}$ namun yang dapat dimanfaatkan sebagai tempat wisata hanya sebesar $13.000 \mathrm{~m}^{2}$. Aktivitas wisata tersebut dilakukan di area sekitar genangan air (mata air), area batang sungai, serta area air terjun.

Dalam perhitungan daya dukung fisik hanya aktivitas wisata bersifat masif saja yang digunakan. Hal tersebut dikarenakan aktivitas wisata masif mampu mendatangkan wisatawan paling banyak dan tidak terkendali. Pemilihan aktivitas berenang, arung jeram, dan piknikpun dipakai karena Wisata Alam Sumber Maron sangat identik dengan ketiga aktivitas wisata tersebut.
Perhitungan Daya Dukung Fisik ini didapat dari hasil modifikasi oleh Fandeli dan Muhammad (2009) yaitu sebagai berikut:

$$
P C C=A x \frac{1}{B} x R f
$$

\section{Keterangan:}

A : Luas area yang digunakan untuk wisata

B : Luas area/ruang gerak yang dibutuhkan oleh seorang wisatawan untuk berwisata dengan tetap memperoleh kepuasan

Rf : Faktor rotasi (lama waktu areal dibuka adalah rata-rata waktu yang diperlukan untuk sekali kunjungan)

Tabel 2.

Luas Area Ruang Gerak Pengunjung

\begin{tabular}{l|l|l}
\hline No. & Pola Aktivtas Rekreasi & Ruang Gerak $\left(\mathbf{m}^{\mathbf{2}}\right)$ \\
\hline 1. & River Tubing & 5.096 \\
\hline 2. & Berenang & 1.592 \\
\hline 3. & Piknik & 6.039 \\
\hline
\end{tabular}

Rf adalah faktor rotasi dimana jam buka obyek wisata dibagi dengan rata-rata durasi kunjungan. Wisata alam sumber maron dibuka mulai pukul 08.00 sampai 16.00 WIB (9 jam). Rata rata waktu berkunjung wisatawan didalam kawasan wisata alam berkisar 3,5 jam .

$$
\begin{aligned}
& \text { Rf }=\frac{\text { Masa Buka }}{\text { Waktu rata }- \text { rata perkunjungan }} \\
& \text { Rf } \quad=\frac{9}{3,5}=2,57
\end{aligned}
$$

Langkah selanjutnya adalah menghitung daya dukung riilnya. Daya dukung riil (Real Carrying Capacity/RCC) merupakan jumlah wisatawan maksimum yang diperkenankan berkunjung ke kawasan Wisata Alam Sumber Maron. Perhitungan RCC didapat dengan perhitungan faktor koreksi $(\mathrm{C} f$ ) yang diambil dari karakteristik obyek yang diterapkan pada PCC yaitu, kepekaan erosi tanah, kelerengan, dan iklim. Variabel tersebut dipilih sebagai faktor koreksi karena dapat mempengaruhi kelestarian ekosistem di area wisata yang dikunjungi dan faktor bencana dalam kawasan. 
Variabel tersebut merupakan faktor pembatas terhadap keberlangsungan interaksi antara wisatawan dan ekosistem di kawasan Wisata Alam Sumber Maron.

Berdasarkan penilaian yang dilakukan terhadap beberapa variabel PCC maka didapatkan nilai faktor koreksi untuk masingmasing variabel. Nilai faktor koreksi tersebut digunakan untuk menghitung daya dukung riil (RCC) yang mengacu pada modifikasi rumus Cifuentes (1992) adalah sebagai berikut:

$R C C=P C C \times C f_{1} \times C f_{2} \ldots \ldots \times C f n$

Keterangan :

PCC : Daya dukung fisik (Physical Carrying Capacity)

Cf : Faktor-faktor koreksi dari parameter biofisik lingkungan

$(C f)=1-\frac{\mathrm{Mn}}{M t}$

Keterangan :

(Cf) : Faktor koreksi biofisik

Mn : Kondisi nyata pada faktor koreksi biofisk

Mt : Batas maksimum variabel

Setelah mendapatkan hasil dari daya dukung riil untu kemudian dilanjutkan dengan perhitungan dya dukung efektif. Hasil perhitungan daya dukung efektif merupakan perhitungan lanjutan dari nilai daya dukung rill/ RCC. Berdasarkan data dan wawancara dengan ketua atau penanggung jawab kepengelolaan, terdapat 12 orang yang aktif bekerja secara efektif setiap hari di lapangan. Perhitungan nilai Daya Dukung Efektif ini diuraikan dengan rumus yang mengacu pada modifikasi rumus oleh Fandeli \& Muhammad (2009) yaitu:

$E C C=R C C \times M C$

Keterangan :

RCC : Daya dukung Rill (Real Carrying Capacity)

MC : Kapasitas manajemen area

$\mathrm{MC}=\frac{R n}{R t} \times 100 \%$
Keterangan :

$R n$ : Jumlah petugas pengelola yang ada

Rt : Jumlah petugas pengelola yang dibutuhkan

Rn : jumlah petugas yang ada adalah 11 orang

Rt : Jumlah petugas pengelola yang dibutuhkan adalah 18 orang

$\mathrm{MC}=\frac{R n}{R t} \times 100 \%$

$\mathrm{MC}=\frac{11}{18} 100 \%$

$\mathrm{MC} \quad=61.11 \%$

\section{PEMBAHASAN}

Berdasarkan informasi yang disampaikan oleh pengelola menjelaskan bahwa Wisata Alam Sumber Maron terbagi menjadi tiga zona badan air yang meliputi kolam dan sungai. Zona A merupakan zona yang terdekat dengan pintu masuk Wisata Alam Sumber Maron dan memiliki luas wilayah sebesar $536 \mathrm{~m}^{2}$. Aktivitas atau atraksi wisata yang dapat dilakukan di zona A adalah berenang untuk anak-anak dan sepeda air. Zona B merupakan zona yang berada tepat di sebelah barat dari zona A dan memiliki luas wilayah sebesar $1056 \mathrm{~m}^{2}$. Zona B memiliki kedalaman berkisar 3 meter dan kerap digunakan wisatawan untuk berenang maupun berfoto di dalam air. Zona $\mathrm{C}$ merupakan zona paling luas diantara ketiga zona lainnya yaitu dengan luas wilayah sebesar $5.895 \mathrm{~m}^{2}$. Zona $\mathrm{C}$ terdapat beragam bentang lahan dengan kontur yang rapat, diantaranya berupa sungai dan air terjun. Wisatawan dapat melakukan berbagai macam aktivitas atau atraksi wisata di zona $C$ mulai dari bersantai dan bermain air saja hingga mencoba atraksi ekstrim yaitu river tubing (arung jeram).

Ketiga zona yang telah dideskripsikan tersebut dihubungkan dengan sebuah jalan setapak yang diikuti juga dengan akomodasi berupa warung dan toilet yang berpola linier terhadap jalan setapak. Berdasarkan data dari pengelola disebutkan saat ini sudah terdapat 53 warung yang terdaftar di Wisata Alam Sumber Maron yang apabila dijumlahkan memiliki luas area sebesar $6.039 \mathrm{~m}^{2}$. 


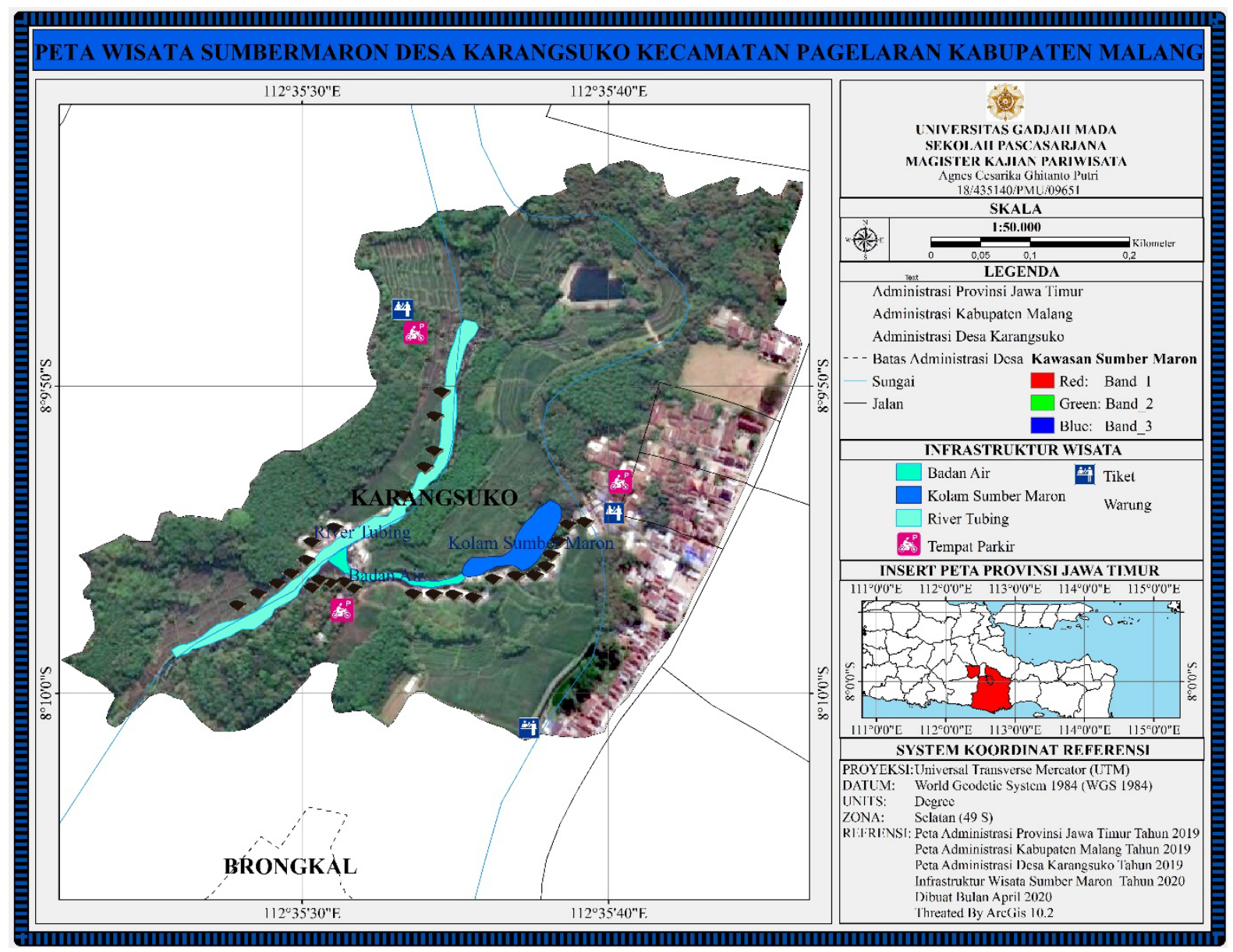

Gambar 4

Peta Wisata Alam Sumber Maron

(Sumber: Dokumen Penulis,2020)

\section{Daya Dukung Lingkungan}

Daya dukung lingkungan yang dianalisis adalah untuk menghitung kapasitas daya tampung ideal dengan memperhitungkan faktor ekologi dan memperhatikan kelestarian ekosistem yang ada dalam kawasan Wisata Alam Sumber Maron pada zona pemanfaatan khusus wisata.

Penggunaan atau pemanfaatan lahan harus mempertimbangkan kesesuaian daya dukung lahan. Penggunaan yang tidak sepenuhnya memanfaatkan daya dukung yang tersedia maka akan terjadi pemanfaatan yang tidak efektif. Penggunaan yang melebihi daya dukung lahan akan mengakibatkan pemanfaatan yang lewat batas. Daya dukung lingkungan digunakan untuk menghitung daya dukung yang aman bagi perkembangan suatu wilayah untuk menghindari kelebihan beban. Daya dukung lingkungan suatu objek wisata alam menunjukkan kemampuan kawasan wisata dalam menampung jumlah wisatawan persatuan waktu tertentu (Soemarwoto, 2004).

\section{Daya Dukung Fisik /PCC}

Daya dukung fisik (Physical Carrying Capacity/PCC) merupakan jumlah maksimum wisatawan yang secara fisik tercukupi oleh ruang yang disediakan pada waktu tertentu. Berdasarkan hasil pengamatan di 
kawasan Wisata Alam Sumber Maron, untuk mengetahui daya dukung fisik kawasan Wisata Alam Sumber Maron diasumsikan memiliki luas seluruhnya $29.610 \mathrm{~m}^{2}$. Luas kawasan yang diproyeksikan dapat digunakan oleh wisatawan untuk aktivitas wisata memiliki luas dengan total sekitar $13.000 \mathrm{~m}^{2}$ meliputi lokasi parkir resmi kendaraan wisatawan, zona $\mathrm{A}$, zona B, Zona $\mathrm{C}$, jalan setapak dan akomodasi (warung dan toilet).

Berdasarkan identifikasi dan wawancara wisatawan di lapangan, terdapat 6 aktivitas yaitu berenang, bersepeda air, menikmati pemandangan alam, bermain air, piknik, dan arung jeram (river tubing). Dari keenam aktivitas tersebut kemudian diklasifikasikan menjadi dua jenis, meliputi aktivitas wisata yang bersifat masif dan bersifat minat khusus. Aktivitas wisata bersifat masif di Wisata Alam Sumber Maron adalah berenang, arung jeram (river tubing), dan piknik, sedangkan aktivitas bersifat minat khusus adalah menikmati pemandangan alam, bermain air, dan bersepeda air.

Menurut Douglass dalam Fandeli \& Muhamad (2009) menjelaskan bahwa kebutuhan area untuk aktivitas wisatawan berdasarkan faktor pemulihan tersebut berbeda-beda. Setiap wisatawan membutuhkan luas area sebesar $27 \mathrm{~m}^{2}$ untuk berenang, $49 \mathrm{~m}^{2}$ untuk berperahu, serta $65 \mathrm{~m}^{2}$ untuk piknik. Terkait dengan nilai untuk aktivitas arung jeram (river tubing) bisa menggunakan standarisasi dari aktivitas berperahu.

Tabel 3.

Perhitungan Daya Dukung Fisik (PCC)

\begin{tabular}{l|l|l|l|l|l}
\hline \multicolumn{1}{c|}{ Aktivitas } & \multicolumn{1}{|c|}{ Ruang Pengelolaan } & $\begin{array}{c}\text { A } \\
\left(\mathbf{m}^{2}\right)\end{array}$ & \multicolumn{1}{c|}{$\begin{array}{c}\mathbf{B} \\
\left(\mathbf{m}^{\mathbf{2}}\right)\end{array}$} & $\begin{array}{c}\mathbf{R f} \\
\mathbf{( k a l i )}\end{array}$ & $\begin{array}{c}\text { Nilai PCC } \\
(\mathbf{p e n g u n j u n g / h a r i})\end{array}$ \\
\hline Berenang & Zona A dan B & 1.592 & 27 & 2,57 & 152 \\
\hline Arung Jeram & Zona C & 5.096 & 49 & 2,57 & 267 \\
\hline Piknik & Warung di kawasan wisata & 6.039 & 65 & 2,57 & 239 \\
\hline Jumlah kunjungan/hari & & 658 \\
\hline Jumlah kunjungan/minggu & & 4.606 \\
\hline
\end{tabular}

Sumber: Data Analisis, 2020

Berdasarkan perhitungan daya dukung fisik/ PCC dari faktor luas area, ruang gerak, dan faktor rotasi didapat nilai PCC yaitu 658 wisatawan/ hari atau 240.170 wisatawan/tahun. Jumlah tersebut merupakan jumlah maksimum wisatawan yang secara fisik dapat mengunjungi Wisata Alam Sumber Maron dengan tetap memperoleh kenyamanan dan kepuasan. Asumsi nilai PCC ini tidak mempertimbangkan waktu puncak (peak-season) maupun hari-hari sepi wisatawan (off-season). Berdasarkan asumsi tersebut maka nilai daya dukung fisik tersebut merupakan nilai kunjungan pada kurun waktu yang sama.

\section{Daya Dukung Rill/RCC}

Terdapat 3 faktor biofisik yang telah ditentukan untuk menghitung RCC dari Wisata Alam Sumber Maron. Faktor biofisik tersebut adalah curah hujan (iklim), kemiringan lereng, dan jenis tanah. Berdasarkan ketiga faktor tersebut dapat menghasilkan nilai 0,925 untuk curah hujan sebagai $\mathrm{Cf}_{1}$, nilai 0,6 untuk kemiringan lereng sebagai $\mathrm{Cf}_{2}$, dan nilai 0,8 untuk jenis tanah sebagai $\mathrm{Cf}_{3}$. Perhitungan daya dukung riil pada Wisata Alam Sumber Maron dapat dilihat pada tabel 4. 
Tabel 4.

Perhitungan Daya Dukung Riil (RCC) Pada Wisata Alam Sumber Maron

\begin{tabular}{|c|c|c|c|c|c|c|}
\hline \multirow[t]{2}{*}{ Aktivitas } & \multirow[t]{2}{*}{ Ruang Pengelolaaan } & \multicolumn{3}{|c|}{ Nilai $C f n$} & \multirow{2}{*}{$\begin{array}{c}\text { PCC } \\
\text { (hari) }\end{array}$} & \multirow{2}{*}{$\begin{array}{c}\text { RCC } \\
\text { (hari) }\end{array}$} \\
\hline & & $\mathrm{Cf}_{1}$ & $\mathrm{Cf}_{2}$ & $\mathrm{Cf}_{3}$ & & \\
\hline Berenang & Zona A dan B & 0,925 & 0,6 & 0,8 & 152 & 67 \\
\hline River Tubing & Zona C & 0,925 & 0,6 & 0,8 & 267 & 119 \\
\hline Piknik & Warung di kawasan wisata & 0,925 & 0,6 & 0,8 & 239 & 106 \\
\hline \multicolumn{5}{|c|}{ Jumlah kunjungan / hari } & & 292 orang \\
\hline \multicolumn{5}{|c|}{ Jumlah kunjungan / minggu } & & 2.045 orang \\
\hline \multicolumn{5}{|c|}{ Jumlah kunjungan / bulan } & & 8.765 orang \\
\hline \multicolumn{5}{|c|}{ Jumlah kunjungan / tahun } & & 106.635 orang \\
\hline
\end{tabular}

Sumber : Data Analisis, 2020

Berdasarkan hasil perhitungan nilai daya dukung rill/ RCC menjadi pertimbangan jumlah wisatawan yang sudah dikoreksi oleh faktor biofisik. Nilai daya dukung riil Wisata Alam Sumber Maron berdasarkan hasil perhitungan adalah 292 wisatawan sehingga estimasi jumlah kunjungan per tahun yang dapat diterima adalah sebanyak 106.635 wisatawan. Pertimbangan nilai daya dukung riil / RCC membantu upaya memelihara keseimbangan antara kondisi lingkungan objek wisata dengan jumlah wisatawan yang berkunjung ke Wisata Alam Sumber Maron.

\section{Daya Dukung Efektif/ECC}

Hasil nilai MC adalah 61,11\%, nilai tersebut berarti bahwa dengan jumlah petugas yang ada saat ini cukup mampu melayani jumlah wisatawan seperti yang tertera pada tabel 5.

Tabel 5.

Perhitungan Daya Dukung Efektif (ECC)

\begin{tabular}{lllrl}
\hline \multicolumn{1}{c}{ Aktivitas } & \multicolumn{1}{c}{ Ruang Pengelolaan } & $\begin{array}{c}\text { Nilai RCC } \\
\text { (wisatawan) }\end{array}$ & $\begin{array}{r}\text { MC } \\
\text { (\%) }\end{array}$ & $\begin{array}{c}\text { Nilai ECC } \\
\text { (wisatawan) }\end{array}$ \\
\hline Berenang & Zona A dan B & 67 & 61,11 & 41 \\
Arung Jeram & Zona C & 119 & 61,11 & 72 \\
Piknik & Warung di kawasan wisata & 106 & 61,11 & 65 \\
\hline Jumlah kunjungan / hari & & 179 \\
\hline Jumlah kunjungan / minngu & & 1.250 \\
\hline Jumlah kunjungan / bulan & & 5.356 \\
\hline Jumlah kunjungan / tahun & & 65.166 \\
\hline
\end{tabular}

Sumber: Data Analisis, 2020

Berdasarkan tabel 5 yang telah ditampilkan di atas, upaya untuk memperhitungkan nilai daya dukung efektif kawasan wisata ini, dapat dilihat bahwa Wisata Alam Sumber Maron ternyata mampu menangani 179 wisatawan perhari untuk berkunjung. Nilai daya dukung efektif ini merupakan nilai akhir dari perhitungan daya dukung lingkungan di
Wisata Alam Sumber Maron. Nilai daya dukung lingkungan ini sudah memperhitungkan faktor fisik, biofisik, dan manajemen objek.

Berikut dapat dilihat perbandingan dari hasil penilaian daya dukung lingkungan yang meliputi nilai PCC, RCC, dan ECC di kawasan Wisata Alam Sumber Maron dengan perhitungan jumlah maksimal harian. 
AGNES CAESARIKA GP, MUHAMAD MUHAMAD, DAN CHAFID FANDELI * STRATEGI PENGELOLAAN PARIWISATA BERKELANJUTAN DI KAWASAN WISATA ALAM...

Tabel 6.

Perhitungan Daya Dukung Lingkungan

\begin{tabular}{llll}
\hline \multicolumn{1}{c}{ Aktivitas } & PCC (wisatawan) & RCC (wisatawan) & ECC (wisatawan) \\
\hline Berenang & 152 & 68 & 41 \\
Arung Jeram & 267 & 119 & 72 \\
Piknik & 239 & 106 & 65 \\
\hline Jumlah kunjungan/hari & 658 & 292 & 179 \\
\hline Jumlah kunjungan / minggu & 4.606 & 2.045 & 1.250 \\
\hline Jumlah kunjungan / bulan & 19.740 & 8.765 & 5.356 \\
\hline Jumlah kunjungan / tahun & 240.170 & 106.635 & 65.166 \\
\hline
\end{tabular}

Sumber: Analisis data , 2020.

Tabel 6 di atas menunjukkan antara angka perhitungan daya dukung lingkungan dengan kondisi yang ada dari jumlah wisatawan Wisata Alam Sumber Maron memiliki perbedaan yang sangat jauh dalam artian bahwa wisatawan benar-benar melebihi kapasitas (over capacity). Hal tersebut perlu dibenahi agar kondisi ekosistem atau lingkungan di Wisata Alam Sumber Maron tetap terjaga dan dapat berkelanjutan.

\section{Analisis Stakeholder}

Analisis Stakeholder digunakan untuk menganalisis tingkat pengaruh dankepentingan stekholder. Pengaruh adalah kekuatan yang dimiliki oleh stakeholder terhadap suatu proyek atau program. Sedangkan kepentingan adalah prioritas yang diberikan oleh proyek untuk memenuhi kebutuhan dari setiap stakeholder. Model analisis stakeholder yang digunakan merupakan model yang diperkenalkan oleh Reed dkk. (2009) dengan tiga tahapan yang meliputi identifikasi stakeholder, klasifikasi dan menggambarkan hubungan antar stakeholder.

Wisata Alam Sumber Maron dikelola oleh 3 pemangku yang berasal dari instansi pemerintah yaitu Pemerintah Desa Karangsuko dan Bumdes "Amanah" dan Badan Pengelola Wisata. Selain itu terdapat pemangku wisata yang berasal dari non-instansi yaitu masyarakat Desa Karangsuko Berdasarkan pengklasifikasian menurut tingkat kepentingan dan pengaruh dari masing-masing stakeholder, dapat dilihat pada tabel 7 .

Tabel 7.

Hasil Skoring Pengukuran Tingkat Kepentingan

\begin{tabular}{l|l|l|l|l|l|l|l|l}
\hline \multicolumn{1}{c|}{ Instansi } & K1 & K2 & K3 & K4 & K5 & $\begin{array}{l}\text { Jumlah } \\
\text { Skoring }\end{array}$ & Kriteria & Keterangan \\
\hline Pemerintah Desa & 5 & 5 & 5 & 4 & 2 & 21 & $\begin{array}{l}\text { Sangat } \\
\text { Tinggi }\end{array}$ & Sangat mendukung pengelolaan \\
\hline Bumdes & 5 & 4 & 3 & 5 & 3 & 20 & Tinggi & Mendukung pengelolaan \\
\hline Badan Pengelola & 4 & 2 & 3 & 5 & 1 & 15 & Sedang & Cukup mendukung pengelolaan \\
\hline Masyarakat & 2 & 4 & 2 & 1 & 5 & 14 & Sedang & Cukup mendukung pengelolaan \\
\hline
\end{tabular}

Sumber: Data Analisis, 2020.

Dari keempat skoring di atas membuktikan bahwa Pemerintah Desa Karangsuko menjadi instansi yang sangat penting dalam kepengelolaan Wisata Alam Sumber Maron. Hal tersebut sesuai dengan struktur organisasi yang menjelaskan bahwa Pemerintah Desa Karangsuko menjadi payung utama dari pemangku yang ada di Wisata Alam Sumber Maron. 
Tabel 8.

Hasil Skoring Pengukuran Tingkat Pengaruh

\begin{tabular}{l|l|l|l|l|l|l|l|l}
\hline \multicolumn{1}{c|}{ Instansi } & P1 & P2 & P3 & P4 & P5 & $\begin{array}{c}\text { Jumlah } \\
\text { Skoring }\end{array}$ & Kriteria & Keterangan \\
\hline Pemerintah Desa & 3 & 3 & 2 & 1 & 4 & 13 & Sedang & Cukup mempengaruhi pengelolaan \\
\hline Bumdes & 4 & 5 & 3 & 1 & 4 & 17 & Tinggi & Mempengaruhi pengelolaan \\
\hline Badan Pengelola & 4 & 3 & 2 & 1 & 4 & 14 & Sedang & Cukup mempengaruhi pengelolaan \\
\hline Masyarakat & 1 & 1 & 2 & 1 & 1 & 6 & Rendah & Kurang mempengaruhi pengelolaan \\
\hline
\end{tabular}

Sumber: Data Analisis, 2020.

Dari data tersebut dapat dinyatakan bahwa yang memiliki tingkat pengaruh tertinggi terhadap pengelolaan di Wisata Alam
Sumber Maron adalah Bumdes Amanah. Sementara untuk yang memiliki pengaruh paling rendah adalah pemerintah desa.

\begin{tabular}{|c|l|}
\hline $\begin{array}{c}\text { Subyek (Subject) } \\
\text { - Masyarakat Desa }\end{array}$ & \multicolumn{1}{|c|}{ Pemain Kunci (Key Players) } \\
& $\begin{array}{l}\text { - Pemerintah Desa Karangsuko } \\
\text { - Bumdes "Amanah" } \\
\text { - Badan Pengelola }\end{array}$ \\
\hline $\begin{array}{c}\text { Pengikut Lain (Crowd) } \\
-\end{array}$ & $\begin{array}{l}\text { Pendukung (Contest Setter) } \\
-\end{array}$ \\
\hline
\end{tabular}

Gambar 5.

Matriks Klasifikasi Stakeholder Sumber: Data Analisis, 2020.

Stakeholder yang termasuk dalam kelompok Key Players adalah Pemerintah Desa Karangsuko, Bumdesa Amanah, dan Badan Pengelola. Key Player merupakan klasifikasi stakeholder yang memiliki pengaruh dan kepentingan yang tinggi dalam pengelolaan Wisata Alam Sumber Maron. Ketiga stakeholder tersebut memiliki peran utama dalam upaya mengembangkan pariwisata di Wisata Alam Sumber Maron.

Stakeholderyang termasuk dalam kelompok subject adalah Masyarakat Desa Karangsuko. Kelompok subject merupakan klasifikasi stakeholder yang memiliki kepentingan tinggi namun pengaruhnya rendah. Stakeholder tersebut memiliki tujuan yang sama, yaitu meningkatkan peran masyarakat dalam pembangunan kepariwisataan agar lebih aktif dan sekaligus menerima manfaat positif.

Hubungan stakeholder dalam pengelolaan Wisata Alam Sumber Maron dapat dilihat melalui hasil wawancara informan kunci. Hasil wawancara informan kunci menjelaskan hubungan antara stakeholder yang terjadi di lapangan. Hubungan antara stakeholder dapat dikelompokkan menjadi tiga kelompok
(Riani, 2012) meliputi hubungan komunikasi, koordinasi dan kerja sama.

\section{Analisis Travel Cost Method (Biaya Perjalanan)}

Biaya perjalanan adalah seluruh biaya yang dikeluarkan oleh pengunjung dalam satu kali perjalanan antara lain biaya konsumsi selama rekreasi, biaya transportasi, biaya dokumentasi, karcis masuk, biaya parkir, biaya videranata, dan biaya lainnya. Secara keseluruhan dihitung dengan rumus. $\mathrm{BPT}=\mathrm{BT}+\mathrm{Bko}+\mathrm{BP}+\mathrm{BTM}+\mathrm{BKM}+$
$\mathrm{BSB}+\mathrm{BL}$

Keterangan:

$\mathrm{BPT}=$ Biaya Perjalanan Total

BT = Biaya Transportasi

Bko = Biaya Konsumsi

$\mathrm{BP}=$ Biaya Parkir

$\mathrm{BTM}=$ Biaya Tiket Masuk

$\mathrm{BKM}=$ Biaya Kamar Mandi

$\mathrm{BSB}=$ Biaya Sewa Ban

$\mathrm{BL}=$ Biaya Loker 
Biaya perjalanan akan disesuaikan dengan biaya-biaya yang dikeluarkan oleh wisatawan di Wisata Alam Sumber Maron. Data yang digunakan pada metode ini adalah dengan mengambil sejumlah 20 responden secara random sampling. Adapun hasil data responden berdasarkan rata-rata biaya perjalanan dapat dilihat pada tabel 9 .

Tabel 9.

Perhitungan Biaya Perjalanan Wisatawan ke Wisata Alam Sumber Maron

\begin{tabular}{l|l|l|l|l|l|l|l|l}
\hline No & \multicolumn{1}{|c|}{ Daerah } & Jumlah & $\begin{array}{c}\text { Biaya } \\
\text { Transportasi }\end{array}$ & $\begin{array}{c}\text { Biaya } \\
\text { Sewa }\end{array}$ & $\begin{array}{c}\text { Biaya } \\
\text { Konsumsi }\end{array}$ & $\begin{array}{c}\text { Biaya } \\
\text { Lainnya }\end{array}$ & Jumlah & $\begin{array}{c}\text { Rata- } \\
\text { rata }\end{array}$ \\
\hline 1 & Malang Raya & 10 & 412.500 & 56.250 & 182.000 & 94.000 & 744.750 & 74.475 \\
\hline 2 & Surabaya & 2 & 95.000 & 55.000 & 46.000 & 18.000 & 214.000 & 107.000 \\
\hline 3 & Sidoarjo & 2 & 250.000 & 15.000 & 20.000 & 23.000 & 308.000 & 154.000 \\
\hline 4 & Bangil & 1 & 50.000 & 7.000 & 5.000 & 25.000 & 87.000 & 87.000 \\
\hline 5 & Gresik & 2 & 160.000 & 27.000 & 38.500 & 18.000 & 243.500 & 121.750 \\
\hline 6 & Kediri & 1 & 50.000 & 5.000 & 5.000 & 10.000 & 70.000 & 70.000 \\
\hline 7 & Jember & 1 & 10.000 & 5.000 & 5.000 & 3.000 & 23.000 & 23.000 \\
\hline 8 & Semarang & 1 & 50.000 & 0 & 0 & 8.000 & 58.000 & 58.000 \\
\hline & jumlah & 20 & 1.077 .500 & 170.250 & 301.500 & 199.000 & 1.748 .250 & $87.412,5$ \\
\hline
\end{tabular}

Sumber: Data Analisis, 2020.

Berdasarkan hasil analisis terhadap 20 responden wisatawan Wisata Alam Sumber Maron dapat dilihat bahwa jumlah nilai biaya perjalanan tertinggi berasal dari Sidoarjo yaitu Rp. 154.000/orang/kunjungan, sedangkan yang terendah berasal dari Kabupaten Jember yaitu sebesar Rp. 23.000/orang/kunjungan. Selain jarak tempuh, yang mempengaruhi tinggi rendahnya biaya perjalanan wisatawan adalah pada faktor kendaraan yang digunakan untuk menuju ke Wisata Alam Sumber Maron. Dari 20 responden tersebut, diketahui bahwa mereka mengendarai sepeda motor, mobil dan bus. Untuk responden yang berasal dari Jember dan Semarang mengendarai bus sehingga biaya transport dapat lebih murah. Besar biaya perjalanan rata-rata yang dikeluarkan wisatawan dari seluruh daerah yaitu sebesar Rp. 87.412,5. Nilai tersebut merupakan daya jual dari Wisata Alam Sumber Maron yang dapat dijadikan sebagai patokan harga untuk perencanaan serta pengembangan kawasan Wisata Alam Sumber Maron dengan tetap memperhatikan keberlanjutan lingkungan dan wisatanya. Persetujuan wisatawanpun ikut ambil bagian dalam penentuan harga baru Wisata Alam Sumber Maron. Berdasarkan hasil wawancara terhadap 20 responden, dihasilkan nilai willingness to pay (keinginan untuk membayar) dapat dinaikkan sebesar 26\%. Pembaharuan harga dari Wisata Alam Sumber Maron bertujuan agar pendapatan operasional dari Wisata Alam Sumber Maron sendiri meningkat serta perekonomian masyarakat penyedia fasilitas atau akomodasi juga meningkat.

\section{Strategi Pengembangan Tata Kelola Wisata Alam Sumber Maron}

Berlandaskan pada Undang-Undang No 10 Tahun 2009 tentang Kepariwisataan di dalam Pasal 4 menjelaskan bahwa kepariwisataan bertujuan untuk meningkatkan pertumbuhan ekonomi dan kesejahteraan masyarakat, menghapus kemiskinan, mengatasi pengangguran, melestarikan alam, lingkungan dan sumber daya dan sebagainya. Landasan tersebut digunakan sebagai pedoman untuk pengembangan pariwisata berkelanjutan yang dapat diterapkan dalam Wisata Alam Sumber Maron.

Pembangunan kepariwisataan dilakukan berdasarkan asas sebagaimana dimaksud dalam pasal 2 yang diwujudkan melalui pelaksanaan rencana pembangunan kepariwisataan dengan 
memperhatikan keanekaragaman, keunikan, dan kekhasan budaya dan alam serta kebutuhan manusia untuk berwisata. Maka dari itu dalam pengembangan dan pembangunan pariwisata berkelanjutan memperhatikan 4 aspek penting disebut sebagai 4 pilar pariwisata yang meliputi industri pariwisata, destinasi pariwista, pemasaran, dan kelembagaan kepariwisataan.

Dengan melihat potensi dan keadaan aktual di Wisata Alam Sumber Maron dapat dibuat sebuah rencana strategis atau rencana pengembangan pariwisata yang akan dideskripsikan satu per satu, yaitu Industri Pariwisata, Destinasi Pariwisata, Pemasaran Pariwisata, dan Kelembagaan Pariwisata.

\section{Industri Pariwisata}

Industri Pariwisata menjadi salah satu aspek penting yang terkandung dalam 4 pilar pembangunan pariwisata. Industri pariwisata meliputi sarana-prasarana dan akomodasi yang ada di sekitar Kawasan Wisata Alam Sumber Maron. Saat ini sudah terlihat bahwa industri pariwisata yang telah berkembang cukup pesat adalah rumah makan (warung). Industri warung ini dinilai berlebihan yang mengakibatkan dampak terhadap kualitas air di Wisata Alam Sumber Maron. Untuk itu maka sangat penting dilakukan pembatasan jumlah warung dalam kawasan wisata ini. Hal tersebut didasari dengan peraturan pemerintah dalam Undang-Undang No 26 Tahun 2007 tentang Penataan Ruang yang mengharuskan adanya ruang terbuka hijau sebesar paling sedikit $30 \%$. Pembatasan warung tersebut guna menjaga ekosistem dari lingkungan Wisata Alam Sumber Maron agar tetap berkelanjutan Warung-warung yang berlebih tersebut dapat dialihkan menjadi industri pariwisata yang lain seperti kamar penginapan bertajuk alam guna memperhatikan dan memperhitungkan length of stay dari wisatawan.

Pemerintah desa atau BUMdesa (Badan Usaha Milik Desa) dapat melakukan peningkatan terhadap kemitraan dari industri pariwisata baik di dalam kawasan wisata maupun di luar kawasan wisata. Hal ini bertujuan agar daerah atau desa yang berada di sekitar Wisata Alam Sumber Maron ikut terdampak baik dengan adanya industri pariwisata tersebut. Hal itu juga dapat meningkatkan pendapatan daerah di tingkat kecamatan.

\section{Destinasi Pariwisata}

Destinasi pariwisata merupakan suatu produk wisata yang dapat disajikan kepada wisatawan yang membuatnya merasa tertarik untuk mengunjungi wisata tersebut. Dalam kasus di Wisata Alam Sumber Maron yang memiliki keunikan tersendiri adalah wisata arung jeram dan berenang. Dengan kedua aktivitas tersebut Wisata Alam Sumber Maron telah mampu menarik perhatian bagi para pengunjung. Pengembangan destinasi wisata dengan tujuan untuk lebih meningkatkan harga dari sebuah tempat wisata adalah dengan menambahkan sarana-prasarana, tata kelola, hingga aktivitas tambahan.

Terdapat beberapa wisata alam yang serupa dengan Wisata Alam Sumber Maron, yaitu Sumber Taman danSumber Jeruk. Kondisi saat ini kedua sumber tersebut tidak seramai Wisata Alam Sumber Maron dikarenakan kurangnya perhatian pemerintah desa untuk mengembangkan destinasi tersebut. Selain itu, wisatawan juga belum begitu mengenal kedua sumber tersebut dikarekan kurangnya promosi. Adanya potensi ini bisa digunakan sebagai antisipasi apabila Wisata Alam Sumber Maron mengalami over capacity sehingga wisatawan dapat dialihkan menuju Sumber Taman dan Sumber Jeruk yang masih dalam satu kawasan Desa Karangsuko.

Terfokus pada Wisata Alam Sumber Maron, selain aktivitas arung jeram, berenang dan piknik, wisatawan juga dapat disuguhkan oleh pemandangan sawah di sekitarnya. Sawah tersebut juga berpotensi untuk digunakan sebagai sebuah wisata edukasi seperti bertani dan bertanam. Kembali memanfaatkan potensi masyarakat di Desa Karangsuko yang tergabung dalam Kelompok Tani "Pangan Makmur" untuk ikut ambil bagian dalam menambah aktivitas di Wisata Alam Sumber Maron ini. Edukasi tersebut dapat berupa penanaman pohon, pembibitan sayuran secara organik dengan media tanah dan juga dengan 
media hidroponik yang memanfaatkan aliran air Sungai Bureng dalam area wisata.

Penambahan aktivitas menjadi sangat penting mengingat bahwa batasan kapasitas dari Wisata Alam Sumber Maron dengan mengandalkan hasil ECC yaitu 179 orang per hari untuk hari biasa (weekday) dan penggunaan nilai PCC yaitu 658 orang perhari pada saat akhir pekan (weekend/peak season). Penambahan aktivitas ini bertujuan untuk meningkatkan investasi wisatawan pada saat berwisata di Wisata Alam Sumber Maron sehingga dengan jumlah wisatawan yang sesuai kapasitas tetap mampu menyeimbangkan dengan pendapatan Wisata Alam Sumber Maron saat belum diberlakukan batasan kapasitas.

\section{Pemasaran Pariwisata}

Hingga saat ini pemasaran telah dilakukan dalam stasiun televisi atau media massa yang bersifat lokal atau sebatas untuk Jawa Timur. Pemasaran merupakan hal yang terpenting dalam meningkatkan motivasi wisatawan untuk datang mengunjungi Wisata Alam Sumber Maron. Pembuatan Tagline dan Branding yang bersifat baru perlu dilakukan untuk upaya meningkatkan nilai ekonomi bahkan nilai dari destinasi wisata itu sendiri. Dengan adanya tagline baru dan branding baru mampu menyasar pengunjung dari seluruh pasar khususnya wisata teruntuk keluarga maupun wisata edukasi untuk study tour. Melalui tagline dan branding baru tersebut calon wisatawan akan mengetahui adanya perubahan atau penambahan aktivitas di Wisata Alam Sumber Maron.

Pembuatan branding baru yaitu "Sumber Maron Permaculture Tourism" dan tagline "Berwisata dan Berkebun dalam Nuansa Pedesaan". Dalam branding baru tersebut mengangkat makna Permaculture Tourism yang berarti pengkombinasian antara wisata alam dan dipadukan dengan aspek pertanian. Aspek pertanian disini adalah pertanian secara tradisional dan organik dengan tidak menggunakan peralatan dan perlengkapan modern. Dapat dijelaskan bahwa Wisata Alam Sumber Maron kini tidak hanya menyajikan sebuah aktivitas wisata arung jeram dan berenang saja, namun juga terdapat berbagai aktivitas wisata edukasi bertajuk pertanian dan perkebunan. Pengangkatan makna permakultur tersebut juga bertujuan agar wisatawan makin peduli dan memperhatikan lingkungan sekitar Wisata Alam Sumber Maron.

Penambahan aktivitas juga berpengaruh terhadap harga yang ditawarkan oleh Wisata Alam Sumber Maron. Wisatawan telah menyetujui apabila harga dari Wisata Alam Sumber Maron diangkat sebesar 26\% dari harga awal. Berdasarkan WTP dari wisatawan tersebut ditentukan harga tiket masuk dari Wisata Alam Sumber maron yang sebelumnya adalah 5.000 rupiah perorang dewasa kini menjadi 6.300 per orang yang bisa dibulatkan menjadi 7.000-10.000 rupiah perorang dewasa. Kenaikan harga juga diikuti dengan jasa penyewaan di dalam kawasan Wisata Alam Sumber Maron seperti penyewaan ban, sepeda air, loker dan toilet sebesar $26 \%$. Biaya perjalanan wisatawan yang menunjukkan nilai dari Wisata Alam Sumber Maron yang mulanya adalah 87.412,5 dapat naik sebesar 26\% menjadi $110.139,8$ rupiah untuk satu wisatawan.

\section{Kelembagaan Pariwisata}

Kelembagaan Pariwisata merupakan pemangku dari adanya wisata tersebut. Pada kasus ini, kelembagaan pariwisata yang mengelola Wisata Alam Sumber Maron yaitu Pemerintah Desa Karangsuko, Bumdesa Amanah, Badan Pengelola dapat kembali meningkatkan kinerja di masing-masing tugas. Pemerintah Desa Karangsuko sebagai key player dari Wisata Alam Sumber Maron dapat melakukan kerjasama dengan agen tour and travel maupun dengan perusahaan yang ingin memberi sponsor terhadap Wisata Alam Sumber Maron namun dengan peraturan dan ketentuan yang telah ditentukan oleh Pemerintah Desa dan Bumdesa juga yang telah disetujui di awal perjanjian kerjasama.

Bumdesa dan Badan Pengelola sebagai stakeholder yang turun lapangan secara langsung memaksimalkan tugasnya untuk mengawasi destinasi wisata serta management pengelolaan baik terkait keuangan maupun pengadaan sarana dan prasarana di lapangan. 
Bumdesa dan Badan Pengelola juga berhak dalam melakukan penyusunan paket wisata dan menentukan rute perjalanan dari wisatawan tersebut di Wisata Alam Sumber Maron. Untuk hal itu sangat diperlukan adanya pelatihan kepariwisataan secara rutin guna meningkatkan mutu sumber daya manusia dari Bumdesa serta Badan Pengelola.

Selain ketiga pemangku wisata yang tergolong instansi pemerintah, terdapat juga pemangku wisata yang sebenarnya begitu dekat dengan tempat wisata. Pemangku wisata tersebut adalah warga Desa Karangsuko sendiri yang telah ambil bagian dalam penyediaan industri pariwisata. Hingga saat ini warga desa telah ambil bagian dalam kegiatan pariwisata meliputi penyediaan warung makan dan penyedia tempat parkir. Dalam perencanaan pengembangan Wisata Alam Sumber Maron perlu mengikutsertakan lebih banyak warga desa untuk bergotong royong meningkatkan perekonomian desa. Perlu juga adanya pelatihan terhadap warga desa setempat guna menumbuhkan kesadaran mereka bahwa mereka tinggal dalam kawasan wisata. Mengikutsertakan masyarakat dalam usaha pariwisata juga merupakan salah satu rencana strategis yang tertuang di dalam Perencanaan Pembangunan Pariwisata Daerah milik Kabupaten Malang yaitu meningkatkan kualitas pariwisata berbasis masyarakat.

\section{SIMPULAN}

Berdasarkan perhitungan daya dukung lingkungan dengan nilai hasil akhir yaitu daya dukung efektif pada lokasi Wisata Alam Sumber Maron adalah 179 orang/hari. Nilai tersebut apabila dimasukkan ke dalam masalah jumlah wisatawan saat ini terlihat jelas melebihi batas daya dukungnya. Pembatasan dan perancangan strategi tata kelola sangat penting dilakukan agar Wisata Alam Sumber Maron dapat berkelanjutan.

Strategi yang dibuat berdasarkan metode 4 pilar yang telah diatur oleh pemerintah pada Undang Undang Nomor 10 tahun 2009 tentang Kepariwisataan. 4 pilar tersebutadalah destinasi pariwisata, industri pariwisata, pemasaran, kelembagaan pariwisata. Dalam strategi yang dilakukan ini adalah Pembaharuan Branding serta Tagline dari Wisata Alam Sumber Maron yang kemudian dikaitkan dengan penambahan atraksi dan industri pariwisata di sekitar Wisata Sumber Maron. Memaksimalkan cara kerja para stakeholder Wisata Alam Sumber Maron agar kelembagaan yang ada mampu membuat Wisata Alam Sumber Maron menjadi wisata yang berkelanjutan.

\section{DAFTAR PUSTAKA}

Anonim.1995. Piagam PariwisataBerkelanjutan. Jakarta: Kementrian Pariwisata.

Anonim. 2018. Data Curah Hujan Kecamatan Pagelaran 2009-2018. BMKG Karangkates. Malang.

Anonim. 2020. Kabupaten Malang Dalam Angka 2019. Kabupaten Malang: BPS

Arida, I Nyoman Sukma. 2015. Ekowisata: Pengembangan, Partisipasi Lokal dan Tantangan Ekowisata. Bali: Cakra Press.

Cifuentes, M. 1992. Tourism Principles and Practice. London: Longman Group.

Damanik, J., dan Weber, E. H.2006. Perencanaan Ekowisata, dari Teori Aplikasi. Pusat Studi Parwisata (PUSPAR) UGM. Yogyakarta: Andi.

Fandeli, C., dan Muhammad. 2009. Prinsipprinsip Dasar Mengkonservasi Lanskap. Yogyakarta: Fakultas Kehutanan, Universitas Gadjah Mada.

Mutaqin, A., Z. 2017. Pariwisata di tahun 2017, Wisata Minat Khusus VS Wisata Massal. Jakarta: Wisata Halimun.

Reed M, Graves A, Dandy N, Posthumus H, Hubacek K, Morris J, Prell C, Quinn CH, Stringer LC. 2009. Who's Nad Why? A Typology of Stakeholder Analysis Methods for Natural Resource Management. Journal of Environmental Management 90:1933-1949.

Riani,M.W. 2012. Mekanisme Hubungan Para Pihak Dalam Pengelolaan Wisata Alam 
di Kota Bandar Lampung dan sekitarnya Provinsi Lampung. Bogor: Institut Pertanian Bogor

Soemarwoto, Otto, 2004. Ekologi Lingkungan Hidup dan Pembangunan Edisi ke 10. Jakarta:Djambatan.

Undang-Undang Republik Indonesia No. 10 Tahun 2009 tentang Kepariwisataan Indonesia
Undang-Undang Republik Indonesia No. 26 Tahun 2007 tentang Penataan Ruang

Utomo, D. H. 2009. Meteorologi Klimatologi dalam studi Geografi. Malang: Universitas Negeri Malang Press.

Utomo,M., Rifai,E.,\& Thahir,A.1993. Pembangunan dan Alih Fungsi Lahan. Lampung:Universitas Lampung 